\title{
Promoting Supplier Diversity in Public Procurement: A Further Step in Responsible Supply Chain
}

\author{
Carol Cravero ${ }^{1,2 *}$
}

\author{
${ }^{1}$ Faculty of Law, University of Turin, Cuneo, ITALY \\ ${ }^{2}$ CRDP, University of Paris Nanterre, FRANCE
}

*Corresponding Author: carol.cravero@gmail.com

Citation: Cravero, C. (2018). Promoting Supplier Diversity in Public Procurement: A Further Step in Responsible Supply Chain. European Journal of Sustainable Development Research, 2(1), 08. https://doi.org/10.20897/ejosdr/80730

Published: January 30, 2018

\begin{abstract}
Public procurement refers to the purchasing of goods, services and works by governments and public authorities. Given the difficulty in defining a common core of social considerations applicable to the generality of public contracts, this paper aims at proposing a distinction between two categories of social objectives: on the one hand, the promotion of work standards and fundamental human rights as a hard core, and on the other hand, the promotion of inclusion and supplier diversity as a further step of the socialoriented approach. This concerns not only the mere procurement process but also the entire supply chain, leading to distinguish between the basic responsible supply chain involving the respect of internationally recognised human and labour rights, and the pro-active responsible supply chain promoting inclusion and supplier diversity. Based on this distinction, this paper analyses if basic working conditions and fundamental rights can be generally taken into account in public procurement. Implications of this assumption affect different levels of the procurement process and policy: from policy considerations to tender design, from economic efficiency matters to monitoring issues.
\end{abstract}

Keywords: social public procurement, responsible supply chain, fundamental human rights, supplier diversity, working conditions

\section{INTRODUCTION}

Public procurement, which refers to the purchasing of goods, services and works by governments and public authorities, constitutes a substantial part of public investment in our economy. ${ }^{1}$ A more strategically focused approach in using this huge amount of public expenditure could lead to "obtain better value for each euro of public money spent and to contribute to a more innovative, sustainable, inclusive and competitive economy". ${ }^{2}$ This

\footnotetext{
${ }^{1}$ Communication from the Commission to the European Parliament, the Council, the European Economic and Social Committee and the Committee of the Regions, COM(2017) 572 final, Making Public Procurement work in and for Europe, Strasbourg, 3.10.2017, p. 2, available at: http://ec.europa.eu/docsroom/documents/25612. Public procurement represents "14\% of the EU GDP, making it a fundamental element of the investment ecosystem".

${ }^{2}$ Communication from the Commission to the European Parliament, the Council, the European Economic and Social Committee and the Committee of the Regions, COM(2017) 572 final, Making Public Procurement work in and for Europe, Strasbourg, 3.10.2017, p. 2, available at: http://ec.europa.eu/docsroom/documents/25612. "Improving procurement is part of the stronger single market, called for in the 2017 State of the Union address of President Juncker". See also C. McCrudden, Buying social justice: equality, Government Procurement, and Legal Change, New York, Oxford University Press, 2015; C. McCruden, "EC public procurement law and equality linkages: foundations for interpretations", in S. Arrowsmith and P. Kunzlik (eds.), Social and Environmental Policies EC Procurement Law. New Directives and New Directions, Cambridge-New York, Cambridge University Press, 2009; S. Arrowsmith, "Horizontal policies
} 
implies a shift in traditional approaches at different stages, from policy considerations to tender design, from (in)efficiency matters to monitoring issues. ${ }^{3}$

This shift seems to be particularly difficult and challenging when it comes to social considerations in public procurement, including the promotion of acceptable, fair and safe working conditions (e.g. minimum wages, and working time, health and safety standards) in compliance with social, labour and human rights, as well as the promotion of social inclusion and employment opportunities for various employee groups, the reduction of the gender pay gap, and the consideration of ethical and fair trade principles. This long (and non-exhaustive) list of social "linkages" 4 of public procurement reflects the complexity of the topic to the extent that these objectives affect different dimensions: from working conditions to various inclusive and social policies. The multidimensional nature of such considerations implies a strong legal framework and a clear prioritization of objectives.

Even if social inclusive policies have already been applied in several national procurement policies, ${ }^{5}$ such as the example of Canadian and U.S. set-asides, social procurement still remains a controversial topic. ${ }^{6}$ Arguments of opponents varies from perceived economic inefficiency issues to lack or weaknesses of monitoring systems. ${ }^{7} \mathrm{In}$ addition, objective difficulties affect contracting authorities when defining social criteria in tendering procedures, being it "both labour- and cost-intensive". ${ }^{8}$ Moreover, these social considerations shall not overlook competition principle, transparency and anticorruption issues.

As a result of scepticisms and objective difficulties in providing and implementing social criteria, strategic procurement possibilities are still not sufficiently used by contracting authorities, as underlined by the European Commission in its recent Communication on "Making Public Procurement work in and for Europe".

However, many different initiatives at both academic and policy level (as well as at the business level itself) have been taken to explore the legal and regulatory challenges of using procurement to promote social objectives, ${ }^{10}$ in particular when considering procurement outcomes as results of (more or less) complex supply chains. While unethical practices amongst suppliers and abuse of human and labour rights in supply chains remain widespread, it is becoming clear that "the tide of opinion is also placing greater responsibility on public purchasers to address the issue, emphasising an increasing need to understand the potential human impacts of our commercial

in public procurement: a taxonomy", in Journal of Public Procurement 10.2 (2010), 149-186; S. Arrowsmith and P. Kunzlik (eds.), Social and environmental Policies in EC Public Procurement Law, Cambridge University Press, 2009; R. Caranta and M. Trybus (eds.), The law of Green and Social Procurement in Europe, Copenhagen, Djøf, 2010; S. L. Schooner and C. R. Yukins, "Public procurement: focus on people, value for money and systemic integrity, not protectionism", in R. Bladwin and S. J. Evenett (eds.) The Collapse of Global Trade, Murky Protectionism, and the Crisis: Recommendations for the G20, London, Centre for Economic Policy Research, 2009; T. Schulten et al., Pay and other social clauses in European public procurement. An overview on regulation and practices with a focus on Denmark, Germany, Norway, Switzerland and the United Kingdom, Düsseldorf, Study on behalf of the European Federation of Public Service Unions - EPSU, 2012, available at: https://www.boeckler.de/pdf/wsi_schulten_pay_and_other_social_causes.pdf; B. Sjafjell and A. Wiesbrock (eds.) Sustainable Public Procurement Under EU Law: New Perspectives on the State as Stakeholder, Cambridge and New York, Cambridge University Press, 2016.

${ }_{3}$ Communication from the Commission to the European Parliament, the Council, the European Economic and Social Committee and the Committee of the Regions, COM(2017) 572 final, Making Public Procurement work in and for Europe procurement, Strasbourg, 3.10.2017, p. 3, available at: http://ec.europa.eu/docsroom/documents/25612. "A shift from a purely administrative approach to a strategically and needsdriven approach, in full compliance with the rules" is required. Moreover, the Commission has identified six priority areas, "where clear and concrete action can transform public procurement into a powerful instrument in each Member State's economic policy toolbox, leading to substantial benefits in procurement outcomes". The first strategic priority underlined is the ensuring of wider uptake of strategic public procurement.

${ }^{4}$ C. McCrudden, Buying social justice: equality, Government Procurement, and Legal Change, New York, Oxford University Press, $2015,13$.

${ }^{5}$ Examples of social linkages in public procurement can be taken from different jurisdictions, from the well-known Affirmative action in the US (starting in the 1960s) for African-American equality, through "the promotion of Canadian aboriginal business development by using selective set-asides for federal procurement", to the "preference point system in South Africa addressing several policy goals dealing with historically disadvantaged categories of persons by unfair discrimination on the basis of race, gender or disability". See R. Roos, Sustainable Public Procurement: Briefing Note, 2012, available at: http://unpcdc.org/media/390120/spp_brief_en_2012-02-06.pdf. See also C. McCrudden, Buying social justice: equality, Government Procurement, and Legal Change, New York, Oxford University Press, 2015; S. Arrowsmith, "Horizontal policies in public procurement: a taxonomy", in Journal of Public Procurement 10.2 (2010), 149-186; p. 53; R. Caranta, "Sustainable Procurement", in M. Trybus, R. Caranta, G. Edelstam (eds.), EU Public Contract Law. Public Procurement and Beyond, Brussels, Bruylant, 2014; D. C. Dragos and B. Neamtu, "Sustainable Public Procurement in the EU: Experiences and Prospects", in F. Lichere, R. Caranta, S. Treumer (eds.), Novelties in the 2014 Directive on Public Procurement, Copenhagen, DJØF Publishing, 2014, p. 67; C. McCruden, "EC public procurement law and equality linkages: foundations for interpretations", in S. Arrowsmith and P. Kunzlik (eds.), Social and Environmental Policies EC Procurement Law. New Directives and New Directions, Cambridge-New York, Cambridge University Press, 2009, 271.

${ }^{6}$ G. Piga and T. Tatrai (eds.), Public procurement policy, London and New York, Routledge, 2016; A. Sanchez Graells, Public procurement and the EU competition rules, (2nd edition), Oxford and Portland, Oregon, Hart Publishing, 2015.

${ }^{7}$ M. Trybus, "Supporting social considerations through public procurement: a legal perspective", in G. Piga and T. Tatrai (eds.), Public procurement policy, London and New York, Routledge, 2016.

${ }^{8}$ O. Martin-Ortega and A. Davies MBA FCIPS, Protecting buman rights in the supply chain. A guide for public procurement practitioners, 2017, p. 23, available at: http://www.hrprocurementlab.org/wp-content/uploads/2017/06/KnowledgeLUPCProtectingHumanRightsintheSupplyChain2.pdf.

${ }^{9}$ Communication from the Commission to the European Parliament, the Council, the European Economic and Social Committee and the Committee of the Regions, COM(2017) 572 final, Making Public Procurement work in and for Europe procurement, Strasbourg, 3.10.2017, p. 5, available at: http://ec.europa.eu/docsroom/documents/25612

${ }_{10}$ See, among others, http://www.hrprocurementlab.org/. 
activities". ${ }^{11}$ In fact, "it would be absurd were hospitals to buy surgical instruments made in factories by workers who routinely suffered injuries because working conditions were so poor. It would be equally unacceptable for universities to buy electronic equipment made in factories where young students are forced to work against their will". ${ }^{12}$ Infrastructure should be put in place "to achieve compliance and pursue good practice to identify, prevent and mitigate the risk of human [and labour] rights violations in our supply chains". ${ }^{13}$

Moreover, other than the compliance with fundamental human and labour rights, social considerations could also lead to achieve further objectives such as the promotion of supplier diversity and social inclusion through responsible supply chain. How to integrate all these considerations in public procurement needs above all a clear needs-prioritization policy in order to avoid "too many competing priorities". ${ }^{14}$

Nevertheless, the definition of a common hard core of social considerations applicable to the generality of public contracts seems to be challenging since different constraints and difficulties exist.

To better focus on this topic, this paper analyses firstly the place of social considerations among strategic objectives and, particularly, their consistency with procurement "primary" objectives (chapter 2). Then, a distinction between two categories of social objectives is proposed: on the one hand, the promotion of work standards and human rights as a hard core, and on the other hand, the promotion of inclusion and supplier diversity as a further step of the social-oriented approach. This concerns not only the mere procurement process but also the entire supply chain, which leads to distinguish between the basic responsible supply chain involving the respect of internationally recognised human and labour rights, and the pro-active responsible supply chain promoting inclusion and supplier diversity (chapters 3 and 4). Implications of this assumption affect different levels of the procurement process: from policy considerations to tender design, from economic efficiency matters to monitoring issues. The paper closes with some conclusions (chapters 5).

\section{STRATEGIC OBJECTIVES OF PUBLIC PROCUREMENT: THE PLACE OF SOCIAL CONSIDERATIONS}

The purchasing of suppliers, services or works meeting both the need of contracting authorities and the price considerations is mostly seen as being the primary objective of public procurement. ${ }^{15}$ The proper and efficient functioning of procurement requires the protection of at least openness, equal-treatment, competition, and transparency principles. However, further objectives have been connected to public procurement policies over time. As already argued, ${ }^{16}$ even if the terminology used to define these objectives varies from "secondary" to "horizontal", ${ }^{17}$ from "strategic" 18 to "sustainable" or just "green and social considerations"19, their main aim remains the same: pushing public procurement policies to go beyond both a price only approach and a "mere administrative procedure" connotation.

According to the recent Communication of the European Commission of October 2017 on "Making Public Procurement work in and for Europe", procurement is defined as a "powerful tool for spending public money in an efficient, sustainable and strategic manner, especially in times of strained national budgets". ${ }^{20}$ More specifically, it is evident the strong emphasis accorded to the strategic objectives, especially when it comes to the contribution that public procurement can make in addressing "many of Europe's major challenges", such as the creation of

\footnotetext{
11 O. Martin-Ortega and A. Davies MBA FCIPS, Protecting buman rights in the supply chain. A guide for public procurement practitioners, 2017, available at: http://www.hrprocurementlab.org/wp-content/uploads/2017/06/KnowledgeLUPC-ProtectingHumanRightsintheSupplyChain2.pdf. 12 O. Martin-Ortega and A. Davies MBA FCIPS, Protecting buman rights in the supply chain. A guide for public procurement practitioners, 2017, available at: http://www.hrprocurementlab.org/wp-content/uploads/2017/06/KnowledgeLUPC-ProtectingHumanRightsintheSupplyChain2.pdf. ${ }_{13}$ O. Martin-Ortega and A. Davies MBA FCIPS, Protecting buman rights in the supply chain. A guide for public procurement practitioners, 2017, available at: http://www.hrprocurementlab.org/wp-content/uploads/2017/06/KnowledgeLUPC-ProtectingHumanRightsintheSupplyChain2.pdf. ${ }^{14}$ O. Martin-Ortega and A. Davies MBA FCIPS, Protecting buman rights in the supply chain. A guide for public procurement practitioners, 2017, available at: http://www.hrprocurementlab.org/wp-content/uploads/2017/06/KnowledgeLUPC-ProtectingHumanRightsintheSupplyChain2.pdf. "Public purchasers are already obliged to line up a long series of hoops for suppliers to jump through, demonstrating not only their technical or financial capability, but their track record on equalities, sustainability and social value".

${ }^{15}$ G. Piga and T. Tatrai (eds.), Public procurement policy, London and New York, Routledge, 2016.

${ }^{16}$ M. Trybus, Supporting social considerations through public procurement: a legal perspective, in G. Piga and T. Tatrai (eds.), Public procurement policy, London and New York, Routledge, 2016, p. 9.

${ }^{17}$ S. Arrowsmith and P. Kunzlik (eds.), Social and environmental Policies in EC Public Procurement Law, Cambridge University Press, 2009.

${ }^{18}$ European Commission, Buying social - A Guide To Taking Account of Social Considerations in Public Procurement, 2010.

${ }^{19}$ R. Caranta and M. Trybus (eds.), The law of Green and Social Procurement in Europe, Copenhagen, Djøf, 2010.

${ }^{20}$ Communication from the Commission to the European Parliament, the Council, the European Economic and Social Committee and the Committee of the Regions, COM(2017) 572 final, Making Public Procurement work in and for Europe, Strasbourg, 3.10.2017, p. 2, available at: http://ec.europa.eu/docsroom/documents/25612
} 
sustainable growth and jobs, the support of the transition to a resource-efficient, energy-efficient and circular economy, and the fostering of sustainable economic development and more equal, inclusive societies. ${ }^{21}$

However, addressing these challenges through public procurement policies raises two main questions. The first is related to the definition of strategic objectives as alien to public procurement policies or as non-extraneous to. ${ }^{22}$ A different definition at this stage has an impact on identifying the most adapted public policy tool to achieve environmental and social objectives. In fact, it is still disputed if public procurement policy is the most appropriate mechanism to take into account these considerations, especially with regards to the social ones. ${ }^{23}$ The second question concerns the effective implementation of environmental and social considerations in national procurement practices. As outlined by the European Commission, strategic procurement possibilities are still not sufficiently used by Member States. ${ }^{24}$

These two questions are closely linked since a wrong definition of the borders of public procurement policies clearly affects their implementation.

If we consider that public procurement is a flexible (i.e. capable of conforming to new needs) and multifunctional policy tool which can serve broader objectives than the mere obtaining of the needed work, good and service at the lowest price, we are recognising that public procurement is not a "mere administrative procedure by which public authorities purchase the basic products, services or works required for their operations". ${ }^{25}$ In other terms, beyond the administrative procedure in itself, there is a public instrument which can be tailored to different policy priorities leading to substantial benefits in procurement outcomes as well as in both the society and the environment.

However, for the opponents to a strategic-oriented approach in public procurement, there is a strong difference between environmental and social considerations, being the first no longer a secondary objective and having a positive impact only. On the contrary, social considerations are often challenged, because they lead to fraud and distortions as well as discretionary on the part of the contracting authority. ${ }^{26}$

However, this does not automatically mean that social considerations are inconsistent with public procurement. Conversely, it implies that social priorities should be clearly defined at a legislative and policy level in a top-bottom approach. ${ }^{27}$ What is usually lacking is a common and clear policy framework identifying priorities and implementation mechanisms, including monitoring systems. Indeed, the effectiveness of social considerations seems to strictly depend to the legislative framework and the policy prioritisation. In fact, many contracting authorities wishing "to further their political objectives to achieve sustainability and social responsibility through procurement do not know exactly how to do so, or are unsure about certain elements". 28

When dealing with social considerations in public procurement (the so-called Socially Responsible Public Procurement - SRPP), different priorities can be taken into account through public procurement policies, from promoting decent work and compliance with human, social and labour rights, to promoting employment opportunities and social inclusion; from promoting accessibility and design for all to ethical trade issues and corporate social

${ }^{21}$ Communication from the Commission to the European Parliament, the Council, the European Economic and Social Committee and the Committee of the Regions, COM(2017) 572 final, Making Public Procurement work in and for Europe, Strasbourg, 3.10.2017, p. 3, available at: http://ec.europa.eu/docsroom/documents/25612

22 M. Trybus, "Supporting social considerations through public procurement: a legal perspective", in G. Piga and T. Tatrai (eds.), Public procurement policy, London and New York, Routledge, 2016. The author emphasises that the German expression for secondary objectives is vergabefremde Aspekte, which linguistically captures this problem and leaves no doubt as to the opinion on these alien aspects. For a different perspective, see G. Piga and T. Tatrai, "Supporting social considerations through public procurement: economic considerations", in G. Piga and T. Tatrai (eds.), Public procurement policy, London and New York, Routledge, 2016.

${ }^{23}$ M. Trybus, "Supporting social considerations through public procurement: a legal perspective", in G. Piga and T. Tatrai (eds.), Public procurement policy, London and New York, Routledge, 2016.

${ }^{24}$ Communication from the Commission to the European Parliament, the Council, the European Economic and Social Committee and the Committee of the Regions, $\operatorname{COM}(2017) 572$ final, Making Public Procurement work in and for Europe, Strasbourg, 3.10.2017, p. 5, available at: http://ec.europa.eu/docsroom/documents/25612

${ }^{25}$ Communication from the Commission to the European Parliament, the Council, the European Economic and Social Committee and the Committee of the Regions, COM(2017) 572 final, Making Public Procurement work, in and for Europe, Strasbourg, 3.10.2017, p. 3, available at: http://ec.europa.eu/docsroom/documents/25612. "A shift from a purely administrative approach to a strategically and needs-driven approach, in full compliance with the rules" is required. Moreover, the Commission has identified six priority areas, "where clear and concrete action can transform public procurement into a powerful instrument in each Member State's economic policy toolbox, leading to substantial benefits in procurement outcomes". The first strategic priority underlined is the ensuring of wider uptake of strategic public procurement.

${ }^{26}$ G. Piga and T. Tatrai, "Supporting social considerations through public procurement: economic considerations", in G. Piga and T. Tatrai (eds.), Public procurement policy, London and New York, Routledge, 2016.

${ }^{27}$ G. Piga and T. Tatrai, "Supporting social considerations through public procurement: economic considerations", in G. Piga and T. Tatrai (eds.), Public procurement policy, London and New York, Routledge, 2016.

${ }_{28}$ The Landmark Project, Success stories in socially responsible public procurement. Using public spending to drive improvements for workers in global supply chains, p. 4, available at: http://www.landmark-project.eu/fileadmin/files/en/LANDMARK_Success_Stories_2014_-_eng.pdf. The Landmark project, running from April 2011 until March 2014, was an international project co-funded by the European Union (Programme Non-State Actors and Local Authorities, managed by EuropeAid) and was formed on the basis of a partnership between seven European organisations including cities, municipalities, national and international expert organisations. 
responsibility (CSR). This long list of social considerations reflects the complexity of the topic to the extent that these objectives affect different dimensions: from working conditions to various social inclusive policies. This complexity makes it difficult to apply one single approach to all the various objectives: one size does not fit all. This is true also when analysing SRPP in (more or less complex) supply chains.

Beyond the number of heterogeneous social objectives, there is also the issue of supply chains' monitoring when it comes to public procurement. In fact, ensuring that "all workers throughout the supply chain are treated appropriately is challenging for procurement personnel", especially when one or more parts of the supply chain occurs in different countries. ${ }^{29}$ Implications of this assumption affect different levels of the procurement process and policy: from policy considerations to tender design, from monitoring requirements to economic efficiency matters. As to the argument about the perceived economic inefficiency of such considerations, economic studies are still too limited to the extent that economic analysis should focus on the global cost and impact of social considerations in a long-term period rather than on the mere costs of procurement outcome.

In the next two sections these issues will be analysed by taking into account the possibility of distinguishing different social objectives, in particular drawing a distinction between, on the one hand, the basic responsible supply chain involving the respect of internationally recognised human and labour rights as a hard core, and on the other hand the pro-active responsible supply chain promoting inclusion and supplier diversity as a further social step.

\section{THE BASIC RESPONSIBLE SUPPLY CHAIN: LEGAL BASIS, LIMITS AND EXPERIENCES}

Business activities and human rights are concepts more and more perceived as being associated with each other: when it comes to intensive commercial activities, labour and human rights are in serious danger of being breached. The political level and the overall society are increasingly aware of this risk and of the consequent need of taking into account business' impacts in terms of (environmental and) social concerns. As economic actors enhancing their commercial activities to their own profit by using the workforce, companies are increasingly perceived as key players in the achievement of decent work, by adopting both a negative (not to violate human rights) and a positive conduct (to adopt protective, preventive and deterrent measures). The establishment of a worker-friendly environment in business activities requires the combination of different measures: from a clear-cut national law imposing certain minima working conditions and rights, to voluntary initiatives of due diligence implemented by each company.

However, when combining human rights with public procurement, the issue is no longer just the promotion of decent, fair and safe work in business, but it calls into questions the potential role and liability of the public buyer. ${ }^{30}$ In other words, if we require that what the contracting authority is buying (and its supply chain) has to respect human and labour rights, we should also ask ourselves to what extent the contracting authority has or can play an active role in checking the compliance with these rights as well as its potential power of sanction in case of non-compliance on the company's side having successfully awarded the public contract. ${ }^{31}$

Before considering the public buyer's role, it is important to identify the legal standards to be used as common references. To assess whether labour and human rights are violated, it should be clearly established the standards to look for. ${ }^{32}$

Human and labour rights are recognised by international standards such as the International Labour Organisation (ILO) Fundamental Conventions, ${ }^{33}$ the United Nation (UN) Human Rights declaration, ${ }^{34}$ the United Nation (UN) Convention on the Rights of the Child, ${ }^{35}$ and the European Human Rights Convention. ${ }^{36}$ Moreover,

\footnotetext{
${ }_{29}$ The Landmark Project, Good Practice in Socially Responsible Public Procurement. Approaches to Verification from Across Europe, p. 4, available at: http://www.landmark-project.eu/fileadmin/files/en/latest-achievements/LANDMARK-good_practices_FINAL.pdf.

${ }^{30}$ For the liability issue, see V. Ulfbeck, "Supply Chain Liability of the Public Buyer?”; in EPPPL 3/2017, 2017 , p. 325-332.

31 V. Ulfbeck, "Supply Chain Liability of the Public Buyer?"; in EPPPL 3/2017, 2017, p. 325-332; O. Martin-Ortega and O. Outhwaite, "Monitoring Human Rights in Global Supply Chains. Insights and policy recommendations for civil society, global brands and academics", in BHRE Research Series, Policy Paper no. 3, May 2017, p. 5, available at: http://www.bhre.org/policy-papers.

32 V. Ulfbeck, "Supply Chain Liability of the Public Buyer?"; in EPPPL 3/2017, 2017, p. 325-332; O. Martin-Ortega and O. Outhwaite, "Monitoring Human Rights in Global Supply Chains. Insights and policy recommendations for civil society, global brands and academics", in BHRE Research Series, Policy Paper no. 3, May 2017, p. 5, available at: http://www.bhre.org/policy-papers.

33 The Eight ILO Fundamental Conventions are the following: No. 29 on Forced Labour (1930); No. 87 Freedom of Association and Protection of the Right to Organize (1948); No. 98 Right to Organize and Collective Bargaining (1949); No. 100 Equal remuneration (1951); No. 105 Abolition of Forced Labour (1957); No. 111 Discrimination (Employment and Occupation) (1958); No. 138 Minimum Age Convention (1973); No. 182 Elimination of the Worst Forms of Child Labour (1999). See http://www.ilo.org/global/standards/introduction-to-international-labour-standards/conventions-and-recommendations/lang-en/index.htm.

34 See http://www.un.org/en/universal-declaration-human-rights/.

35 http://www.ohchr.org/EN/ProfessionalInterest/Pages/CRC.aspx.

36 http://www.echr.coe.int/Documents/Convention_ENG.pdf.
} 
the United Nations (UN) Guiding Principles on Business and Human Rights (UNGP), published in 2011, set out the principles that govern the relationship between commercial activities and human rights, while the OECD Guidelines for Multinational Enterprises (EMNs) provide a set of government-backed recommendations on responsible business conduct to encourage the positive contributions MNEs can make to sustainable development by minimising the difficulties to which their various operations may give rise. ${ }^{37}$

The reference to these international standards implies the question on their enforceability within States' territories, since there is a need of an adequate implementation and enforcement to make international standards effective in the national legal frameworks. ${ }^{38}$ In addition to the international standards and the domestic legislation protecting human rights (such as, among others, the United Kingdom's Modern Slavery Act of 2015), ${ }^{39}$ there are also standards that suppliers can adopt on a voluntary basis.

This is the case, among others, of the Base Code of the Ethical Trading Initiative (ETI Base Code)". 40 This Code covers nine principles, namely: employment is freely chosen; freedom of association and the right to collective bargaining; working conditions are safe and hygienic; child labour shall not be used; living wages are paid; working hours are not excessive; no discrimination is practiced; regular employment is provided; no harsh of inhumane treatment is allowed. But this is not the only corporate sustainability's initiative.

Another example is the UN Global Compact which is a United Nations initiative to encourage business to adopt sustainable and socially responsible policies, as well as to report on their implementation. Under the Global Compact, companies undertake to operate in "ways that, at a minimum, meet fundamental responsibilities in the areas of human rights, labour, environment and anti-corruption". ${ }^{41}$ With regards to human rights, the first two principles state that "[B] usinesses should support and respect the protection of internationally proclaimed human rights and make sure that they are not complicit in human rights abuses", while on labour issues it is provided that businesses should take actions to eliminate in their supply chains all forms of forced, compulsory and child labour as well as of discrimination in employment and occupation. ${ }^{42}$

When considering these standards and initiatives in public procurement, it may be observed that a common legal implementing framework seems to be still lacking. This lack has an impact on the contracting authorities' conduct since they do not know exactly how to implement sustainability and social responsibility through procurement, or are unsure about certain elements. ${ }^{43}$

This uncertainty is partly due to the fact that social considerations are still perceived as being secondary objectives. This has implied a less strong emphasis on them and a consequent mild legislative action. One of the major difficulties for considering social dimension as a no-more-secondary objective of purchasing policy consists of going beyond a narrow definition of public procurement as a simply administrative action which exclusively aims at obtaining the needed outcome at the lowest possible price. Opposite to this restrictive approach is the broader definition of public procurement as a public policy tool which can be used to achieve different types of objectives (this after an appropriate prioritizing framework, of course). With regards to the multiplicity of

\footnotetext{
${ }^{37}$ http://mneguidelines.oecd.org/responsible-business-conduct-matters.htm.

38 O. Martin-Ortega and O. Outhwaite, "Monitoring Human Rights in Global Supply Chains. Insights and policy recommendations for civil society, global brands and academics", in BHRE Research Series, Policy Paper no. 3, May 2017, p. 5, available at: http://www.bhre.org/policypapers; V. Ulfbeck, "Supply Chain Liability of the Public Buyer?"; in EPPPL 3/2017, 2017, p. 325-332.

39 http://www.osce.org/magazine/302931. The United Kingdom’s Modern Slavery Act (2015) is a "good example of legislation designed to tackle forced labour and human trafficking. Its provision on transparency in supply chains requires businesses with a turnover exceeding a certain level to publish a statement either detailing steps they have taken to ensure that slavery and human trafficking are not taking place in their operations and supply chain, or explicitly stating that no such steps have been taken". See also http://www.legislation.gov.uk/ukpga/2015/30/contents/enacted. Other governments "have taken advantage of modern information technology to develop tools that support voluntary efforts by businesses and consumers to make purchasing choices that avoid goods produced with forced labour. The German government has launched a portal - also available as a smartphone app (www.siegelklarheit.de) - which presents and compares environmental and social labels for textiles, paper, computers and household products, explaining what each label stands for and ranking them. The United States Department of Labour has developed the app Sweat \& Toil, which documents forced labour, particularly child labour, worldwide (www.dol.gov/dol/apps/ilab.htm)".

${ }^{40}$ www.ethicaltrade.org; see also O. Martin-Ortega and A. Davies MBA FCIPS, Protecting human rights in the supply chain. A guide for public procurement practitioners, 2017, available at: http://www.hrprocurementlab.org/wp-content/uploads/2017/06/KnowledgeLUPCProtectingHumanRightsintheSupplyChain2.pdf. ETI's approach to human rights due diligence is based on multi-stakeholder engagement and processes that include: assessment of actual and potential human rights risks; mitigation of risk and remediation for workers impacted by human rights violations; identification of corporate leverage and responsibility, decision-making and actions needed, monitoring, review, reporting and continuous improvement.

41 www.unglobalcompact.org/what-is-gc/mission/principles. The UN Global Compact's ten principles are derived from the Universal Declaration of Human Rights, the International Labour Organization's Declaration on Fundamental Principles and Rights at Work, the Rio Declaration on Environment and Development, and the United Nations Convention Against Corruption.

42 See principles No. 4-5-6 of the UN Global Compact, www.unglobalcompact.org/what-is-gc/mission/principles.

${ }^{43}$ The Landmark Project, Success stories in socially responsible public procurement. Using public spending to drive improvements for workers in global supply chains, p. 4, available at: http://www.landmark-project.eu/fileadmin/files/en/LANDMARK_Success_Stories_2014_-_eng.pdf. The Landmark project, running from April 2011 until March 2014, was an international project co-funded by the European Union (Programme Non-State Actors and Local Authorities, managed by EuropeAid) and was formed on the basis of a partnership between seven European organisations including cities, municipalities, national and international expert organisations.
} 
objectives achievable by public procurement, it seems necessary to distinguish between, on the one hand, human and labour rights as a hard core and, on the other hand, social inclusive policies as a further step of the socialoriented approach.

Concerning fundamental human and labour rights, States must live up to their international obligations ensuring that these rights are observed within their territories. This implies that, when defining their public policies, they have to take into account internationally recognised human and labour rights, the respect of which is a requisite for the policies' lawfulness.

As a consequence, if we define public procurement as being a broader public policy tool instead of a simple administrative action exclusively based on the lowest-price approach, we assume that public procurement policy could not be designed by overlooking human rights issues. Otherwise, there would be a contradiction between procurement policy and the domestic legal system as set up after acceptation and incorporation of international standards: while other public policies lawfully take into account the human and labour rights, public procurement policy would be exempt from caring about them, despite the international State's commitment to respect these standards.

However, this assumption is not free of problematic issues, such as the monitoring and the economic efficiency matters, especially when it comes to (more or less) complex supply chains.

The monitoring issue consists of a three-fold problem: how to monitor in a legally compliant manner, ${ }^{44}$ who should monitor, and the related costs. Indeed, the exclusion of child and forced labour and the measures related to workers' health and safety need to be verifiable in a transparent and effective way. However, achieving this can be "both labour- and cost-intensive" 45 as well as "time-consuming and complex for suppliers and buyers alike", ${ }^{46}$ especially when it comes to complex supply chains using subcontractors or workers located abroad, the working conditions of which still remain difficult to verify (being under foreign legal systems probably using different working conditions as terms of reference, as with regards to minimum wages).

In past and recent experiences, a certain number of instruments of verification has been used "at the various stages of a procurement process (pre-procurement, selection or exclusion criteria, technical specifications, award criteria and contract performance clauses/contract management)" ${ }^{47}$ For instance, in Europe different verification schemes have been developed, such as the Swedish follow-up questionnaire, the German bidder declaration, the Dutch transparency and disclosure of information, and the Swiss external audits. ${ }^{48}$ If in Germany it is common practice to place social criteria within contract clauses by using a bidder declaration as a means to integrate labour and social standards into the international production process, ${ }^{49}$ in Sweden a follow-up questionnaire is used to verify bidders' given declarations. This questionnaire contains fifteen questions that "refer to the inner structure of the contractor, the arrangements between the contractor and his suppliers, knowledge of the contractor about the processes of his suppliers as well as measures that the contractor has taken to ensure compliance with social and ethical requirements throughout its supply chain and the foreseen instruments to address problems in this field". ${ }^{0}$ According to the "Social contract terms" of the Sweden National Agency for Public Procurement, the

${ }_{44}$ The Landmark Project, Verifying Social Responsibility in Supply Chains. A Practical and Legal Guide for Public Procurers, p. 5, available at: http://www.landmark-project.eu/fileadmin/files/en/latest-achievements/LANDMARK-legal_guidance-www.pdf.

45 O. Martin-Ortega and A. Davies MBA FCIPS, Protecting buman rights in the supply chain. A guide for public procurement practitioners, 2017, p. 23, available at:

ProtectingHumanRightsintheSupplyChain2.pdf.

${ }^{46} \mathrm{http}:$ / / www.landmark-project.eu/fileadmin/files/en/latest-achievements/LANDMARK-good_practices_FINAL.pdf.

47 The Landmark Project, Verifying Social Responsibility in Supply Chains. A Practical and Legal Guide for Public Procurers, p. 9, available at: http://www.landmark-project.eu/fileadmin/files/en/latest-achievements/LANDMARK-legal_guidance-www.pdf.

48 The Landmark Project, Verifying Social Responsibility in Supply Chains. A Practical and Legal Guide for Public Procurers, p. 5-9, available at: http://www.landmark-project.eu/fileadmin/files/en/latest-achievements/LANDMARK-legal_guidance-www.pdf. This document takes into account other verification schemes which are "based on cooperation with multi-stakeholder initiatives (MSIs), certification schemes from labels such as Fairtrade International, Forest Stewardship Council (FSC) and XertifiX, and sector-specific approaches for timber, construction materials and textiles".

${ }^{49}$ The Landmark Project, Verifying Social Responsibility in Supply Chains. A Practical and Legal Guide for Public Procurers, p. 13-21, available at: http://www.landmark-project.eu/fileadmin/files/en/latest-achievements/LANDMARK-legal_guidance-www.pdf. A bidder declaration is a "signed document, a self-declaration by the bidder used to verify compliance with certain criteria. The aspects declared can be included into the actual contract clauses of the contract between the contracting authority and the successful bidder". However, "some of the bidder declarations significantly differ in their specific details. Some municipalities work with graduated bidder declarations, which allow suppliers to adopt targeted measures to improve their supply chain practices, while others insist on the presentation of evidence that such measures have already been introduced".

50 The Landmark Project, Veriffing Social Responsibility in Supply Chains. A Practical and Legal Guide for Public Procurers, p. 23, available at: http://www.landmark-project.eu/fileadmin/files/en/latest-achievements/LANDMARK-legal_guidance-www.pdf. A bidder declaration is a "signed document, a self-declaration by the bidder used to verify compliance with certain criteria. The aspects declared can be included into the actual contract clauses of the contract between the contracting authority and the successful bidder". However, "some of the bidder declarations significantly differ in their specific details. Some municipalities work with graduated bidder declarations, which allow suppliers to adopt targeted measures to improve their supply chain practices, while others insist on the presentation of evidence that such measures have already been introduced". 
supplier must ensure, among others, that it does not contribute directly or indirectly to violations to human rights (for instance, when the supplier fails to ask questions about violations of human rights or benefits from violations committed by a third party). ${ }^{51}$ The contractor is also required to provide supporting documents "to show its efforts and the efforts its subcontractors have gone to in ensuring the required social conditions in the production stage are met". ${ }^{22}$ Also in Switzerland the bidders are "asked to send certificates and other documents to show their compliance with the ILO core convention for labour standards (including information on important subcontractors - so called key third parties)". ${ }^{3}$ When there is no prior certification submitted by the best ranked bidder and there is a risk branch/product, an external audit has to be conducted. If the audit shows "no major violations of core labour standards the bidder is accepted and the contract can be awarded". ${ }^{54}$ If the audit shows major violations of core labour standards the bidder "can be excluded and the process starts again with the second best ranked bidder". ${ }^{55}$

Given this fragmented framework of different experiences, a shift to a strategically and needs-driven policy approach ${ }^{56}$ seems to be necessary in the interest of consistency. Needs should be clearly set up at a general policy level with consequent definition of verification measures to be adopted, so that the issue would not be shouldered only by the contracting authorities with a fragmented patchwork of experiences and results. In fact, the approaches towards verification and monitoring chosen by the public authorities differ "both in focus (e.g. exclusion of child labour, core ILO Conventions or other ethical trading objectives) and extent (e.g. simple bidder declarations, codes of conduct, labels and certification, follow-up questionnaires and audits)" ${ }^{57}$ Different roles are currently played by contracting authorities and various measures/sanctions are adopted: from non-compliant bidder's exclusion (for instance, in the Swiss experience) to the request against non-compliant bidders to adopt appropriate mechanisms taking into account the fundamental human and labour rights in their supply chains.

In general, suppliers must have procedures in place to evaluate the risk in their supply chains with regards to potential violations of human rights through their activities, while public authorities can play an active role in taking into account social conditions and verifying the compliance with fundamental human and labour rights.

This is particularly challenging when it comes to complex supply chains where suppliers, buyers, manufacturers and sub-contractors may all be at various levels of development within non-homogeneous legal frameworks referring to different working conditions (such as minimum wages). In fact, "the characteristics of modern global supply chains - such as, stages of the production process spread across diverse countries, short lead times, and short-term buyer-supplier relationships - can reduce visibility and control over an enterprise's supply chain and can make and create challenges for enterprises to meet their responsibilities". ${ }^{8}$

After the tragic collapse of the Rana Plaza factory in 2013 (Bangladesh), "which took away 1,135 lives and caused injury and suffering to many more", the international community was confronted "with the gravest failure of the textiles and garment supply chain in securing the safety of workers". ${ }^{59}$ Sectoral guidelines have therefore been developed by the OECD in order to help enterprises identify and respond to risks of adverse impacts associated with particular sectors. ${ }^{60}$ Moreover, different steps for the improvements of building and fire safety at

\footnotetext{
${ }^{51}$ See the Appendix: Social responsible production - background of Sweden National Agency for Public Procurement, January 2014, available at: http://www.upphandlingsmyndigheten.se/en/sustainable-public-procurement/sustainable-procurement-criteria/office-and-

textiles/furniture/furniture/socially-responsible-production/\#bas

52 The Landmark Project, Verifying Social Responsibility in Supply Chains. A Practical and Legal Guide for Public Procurers, p. 23, available at: http://www.landmark-project.eu/fileadmin/files/en/latest-achievements/LANDMARK-legal_guidance-www.pdf. A bidder declaration is a "signed document, a self-declaration by the bidder used to verify compliance with certain criteria. The aspects declared can be included into the actual contract clauses of the contract between the contracting authority and the successful bidder". However, "some of the bidder declarations significantly differ in their specific details. Some municipalities work with graduated bidder declarations, which allow suppliers to adopt targeted measures to improve their supply chain practices, while others insist on the presentation of evidence that such measures have already been introduced".

53 The Landmark Project, Verifying Social Responsibility in Supply Chains. A Practical and Legal Guide for Public Procurers, p. 35-36, available at: http://www.landmark-project.eu/fileadmin/files/en/latest-achievements/LANDMARK-legal_guidance-www.pdf.

${ }^{54}$ The Landmark Project, Verifying Social Responsibility in Supply Chains. A Practical and Legal Guide for Public Procurers, p. 35-36, available at: http://www.landmark-project.eu/fileadmin/files/en/latest-achievements/LANDMARK-legal_guidance-www.pdf.

55 The Landmark Project, Verifying Social Responsibility in Supply Chains. A Practical and Legal Guide for Public Procurers, p. 35-36, available at: http://www.landmark-project.eu/fileadmin/files/en/latest-achievements/LANDMARK-legal_guidance-www.pdf. The best ranked bidder has to "provide a positive audit or a SA 8000 certificate or any other appropriate means of proof, or if it is not likely that a breach of ILO core conventions is common in the branch" to get the contract.

${ }^{56}$ Communication from the Commission to the European Parliament, the Council, the European Economic and Social Committee and the Committee of the Regions, COM(2017) 572 final, Making Public Procurement work in and for Europe, Strasbourg, 3.10.2017, p. 3, available at: http://ec.europa.eu/docsroom/documents/25612.

57 The Landmark Project, Good Practice in Socially Responsible Public Procurement. Approaches to Verification from Across Europe, p. 4, available at: http://www.landmark-project.eu/fileadmin/files/en/latest-achievements/LANDMARK-good_practices_FINAL.pdf.

58 OECD, Due Diligence Guidance for Responsible Supply Chains in the Garment and Footwear Sector, 2017.

59 OECD, Statement by the National Contact Points for the OECD Guidelines on Multinational Enterprises. One Year After Rana Plaza, 2014.

${ }^{60} \mathrm{http}: / /$ mneguidelines.oecd.org/guidelines/.
} 
garment factories were adopted across Bangladesh. ${ }^{61}$ However, despite the international mobilisation, the textile and garment sector still remains a high-risk area together with (among others) extractives, mineral and agricultural supply chains. A new accident happened in July 2017 at "Multifabs Ltd" textile factory in Bangladesh but it has mostly passed over in silence in Europe. Ten people were killed by a boiler explosion and many have been injured. ${ }^{62}$ Even if national authorities have defined this event as being "a stray accident", ${ }^{3}$ this shows that more work still needs to be done.

Apart from responsible business conduct, an institutional multi-level approach is also required, by ensuring the involvement of several actors including contracting authorities when dealing with responsible public procurement. However, this is a difficult task if contracting authorities are asked to address (all) risks effectively, without having, for the most part, the appropriate resources or know-how to do it and, worse, within an unclear legal reference framework.

However, these difficulties could be partly overcome "by working collectively", which could lead public authorities to "share costs, share information and help to drive improvement in common supply chains, with benefits for everyone involved". ${ }^{64}$ Another support could come from using "non-governmental organisations, purchasing consortia and collaborative supply chain monitoring organisations", which could "help public authorities successfully develop and implement a human rights due diligence strategy". ${ }^{65}$

Creating forms of collaboration between public authorities could allow a better risk assessment - by sharing experiences and experts - and a less-costly monitoring system - by sharing common verification schemes on fundamental human and labour rights' compliance -, making the consideration of this social dimension a feasible and, to some extent, measurable undertaking also in public procurement. As to the related costs, this form of collaboration between public authorities could reduce the economic impact of both monitoring and professionalization-need if undertaken by a number of contracting authorities instead of a single one.

Considering fundamental human and labour rights as a hard core of every public policy tool including the procurement one seems to be an achievable objective to the extent that a common legal reference framework is adopted at a general policy level (for the identification of both the standards to look for and the procurement stages to be considered) and forms of collaboration in monitoring activities are provided between contracting authorities so that waste of time, and of financial and human resources is reduced.

All in all, when considering public procurement, the responsible supply chain guaranteeing the compliance with fundamental human and labour rights should be seen as the standard approach in business and public buyers' activities. As a basic responsible supply chain, it forms an essential minimum and ineradicable core in the broader social dimension, standing in opposition to the pro-active supply chain which represents a further step in the socialoriented approach given its further objective in promoting social inclusive policies.

\footnotetext{
${ }^{61}$ OECD, Statement by the National Contact Points for the OECD Guidelines on Multinational Enterprises. One Year After Rana Plaza, 2014. "Significant steps have been taken since to address the challenge in Bangladesh: those undertaken by the Bangladesh government under the Bangladesh National Tripartite Plan of Action on Fire Safety and Structural Integrity; those adopted by the multilateral policy community, ILO Better Work Program, the EU-US-Bangladesh-Sustainability Compact; and supply chain initiatives such the Bangladesh Accord on Fire and Building Safety and the Alliance for Bangladesh Worker Safety".

${ }^{62}$ See, among others, https://www.usnews.com/news/world/articles/2017-07-03/at-least-nine-people-killed-in-bangladesh-factory-blast; http://about.lindex.com/en/concerning-the-accident-at-multifabs-ltd-factory-in-bangladesh/.

${ }^{63}$ See https://www.usnews.com/news/world/articles/2017-07-03/at-least-nine-people-killed-in-bangladesh-factory-blast.

${ }^{64}$ O. Martin-Ortega and A. Davies MBA FCIPS, Protecting human rights in the supply chain. A guide for public procurement practitioners, 2017, p. 23, available at: http://www.hrprocurementlab.org/wp-content/uploads/2017/06/KnowledgeLUPCProtectingHumanRightsintheSupplyChain2.pdf. According to the authors, public authorities "can collaborate regionally, nationally and internationally in monitoring supply chains to much greater effect. Sectors within public service, such as local government, higher education and health, where supply chains are common to many public authorities, offer particular opportunities for collaboration. Sharing resources means more monitoring, auditing and more effective intelligence gathering can be done. It also means increased leverage and better expertise when negotiating with the global brands - far better than public authorities could hope to achieve on their own".

65 O. Martin-Ortega and A. Davies MBA FCIPS, Protecting human rights in the supply chain. A guide for public procurement practitioners, 2017, p. 23, available at: http://www.hrprocurementlab.org/wp-content/uploads/2017/06/KnowledgeLUPCProtectingHumanRightsintheSupplyChain2.pdf. According to the authors, "collaboration will also help to educate and raise greater awareness of the issues, getting more people involved in the process". Moreover, working in collaboration "can help to ease the financial burden of this and helps gauge where the supply base is at now and where specific issues exist that need to be addressed by the market". An example of such a collaboration between public authorities is Electronics Watch, which is "an independent monitoring organisation that assists public sector buyers to meet their responsibility to protect the labour rights of workers in their global electronics supply chains more effectively and less expensively than any single public sector buyer could accomplish on its own". Suppliers are required "to perform due diligence to identify, prevent and mitigate risk of breach, remedy actual breaches, and compensate workers affected by the breaches, consistent with the UN Guiding Principles". See also http://electronicswatch.org/en/our-story_2459916.
} 


\section{THE PRO-ACTIVE RESPONSIBLE SUPPLY CHAIN: A FURTHER STEP}

The promotion of supplier diversity through supply chains is an ambitious aim which goes beyond the (mere) human and labour rights' compliance. It implies the provision of advanced social policies ${ }^{66}$ in responses to specific social needs. For instance, different supplier diversity programs have been established by States in order to promote the development and inclusion of women owned, minority owned, and else certified diverse businesses within the supply chain. This is the case, among others, of the Canadian policies supporting Aboriginal businesses.

Over the years, the provision of various supplier diversity programs have shown that public procurement can play an important role in stimulating entrepreneurial activity of disadvantaged or minorities' groups and in providing opportunities to workers generally excluded from the labour market. ${ }^{67}$ These specific procurement policies lead to the involvement of less-competitive bidders that would have no chance in a competitive market. This involvement can be set up through preferential or facilitative programs. The former tends to create concrete business opportunities and includes set-aside programs, while the latter seeks to help and encourage specific bidders to participate in public purchasing (for instance, dividing large procurement into reasonably small lots). ${ }^{68}$

With regards to set-asides, certain public contracts are reserved to specific bidders meeting a number of criteria, ${ }^{69}$ including small businesses in general, as well as specific classes of small businesses, such as womenowned businesses, minority-owned businesses, disadvantaged socio-economic operators, businesses operating in economically disadvantaged areas, etc. Through set-asides, contracting authorities are permitted to limit full and open competition, barring large businesses from bidding for certain contracts that are made available only to certain specific less-competitive business. ${ }^{70}$ According to these procurement policies, governments can both promote supplier diversity, involving less-competitive bidders in public procurement processes, and create employment opportunities - through the involvement of these bidders - for workers who are generally excluded from the labour market. However, the legitimacy of the set-asides approach in public procurement is often criticised for its inconsistency with the competition principle.

Among the national legal frameworks having implemented this strategy (USA, Canada, South Africa, etc.), the United States have a long tradition of set-aside contracts for special classes of small businesses. This broad use of set-asides in the US has been justified by the fact that small businesses have historically been considered the backbone of American culture. ${ }^{71}$ Over the years, the notion of small business has grown to include women-owned small business (WOSB), economically disadvantaged women-owned small business (EDWOSB), veteran-owned small business (VOSB), service-disabled veteran-owned small business (SDVOSB), historically underutilized business zone (HUBZone), small disadvantaged business under the Small Business Administration's 8(a) Business Development Program, ${ }^{72}$ etc. Moreover, according to the 1988 Robert T. Stafford Disaster Relief and Emergency

${ }^{66}$ S. Costantini, La Finalizzazione Sociale degli Appalti Pubblici. Le "Clausole Sociali" fra Tutela del Lavoro e Tutela della Concorrenza, in Working Papers CSDLE Massimo D’Antona.it, 2014, available at: http://csdle.lex.unict.it.

${ }^{67}$ H. Friedman, "Why Small Business Self-Certification should be Abolished and Replaced: A Case Against Fraud", in Journal of Contract Management 12, 2014

50. Accordingly, $65 \%$ of all new job creation occurs through small businesses.

${ }^{68}$ W. Kirkwood, "The evolution of small business preferences in the United States and selected lessons learned for the European Union", EPPPL 4/2016, 2016.

${ }^{69}$ To win a set-aside contract, small businesses must meet specific requirements, primarily related to their size, revenue, and independent ownership. Some certifications, generally in the form of self-declarations, are provided to ensure the company is truly qualified to receive set-aside contracts. "This allows the government to take portions of contracts that would have gone to large businesses and set-aside portions of those contracts for small businesses, effectively reducing the amount of revenue awarded to large businesses". J. M. Clapp, Are Small Business Set-Asides Successful?, http://www.academia.edu/7353444/Are_Small_Business_Set-Asides_Successful, p. 5.

${ }^{70}$ The restriction of eligible bidders through the use of set-asides is open to criticism due principally to the negative impact on the competition principle.

${ }^{71}$ J. M. Clapp, Are Small Business Set-Asides Successful?, http://www.academia.edu/7353444/Are_Small_Business_Set-Asides_Successful, p. 1. "It has been said that $65 \%$ of all new job creation occurs through small businesses. Consequently, the federal government has sought to favour small business to ensure their continued existence. This strategy, although it goes against the basic principles of government contracting which focuses on the best value to the taxpayer, has been implemented through a number of laws that ensure a percentage of all government contracts will be awarded to small businesses by limiting who can bid on those contracts". See also H. Friedman, "Why Small Business Self-Certification should be Abolished and Replaced: A Case Against Fraud", in Journal of Contract Management 12, 2014, p. 50. See also U.S. Gov't Accountability Office, Gao-10-673t, Department of Veteran Affairs: Preliminary Observations on Issues Related to Contracting Opportunities for Veteran-owned Small Businesses, 2010, www.gao.gov/new.items/d10673t.pdf. This set-aside policy "reflects a national consensus on the importance of small businesses in the national economy".

${ }^{72}$ The 8(a) Business Development Program is a business assistance program for small disadvantaged businesses. The 8(a) Program offers a broad scope of assistance to firms that are at least $51 \%$ owned and controlled by socially and economically disadvantaged individuals. In particular, under the authority of the Small Business Administration's 8(a) business development program, contracts are set aside for "socially and economically disadvantaged small business concerns," which include firms at least $51 \%$ owned and unconditionally controlled by ANCs, Indian tribes, Native Hawaiian Organizations (NHOs) or Community Development Corporations (CDCs). In 1992, Native Corporations were to be considered "economically disadvantaged" for all purposes of federal law. More specifically, while contracts whose value exceeds the so-called "competitive threshold" are supposed to be set aside for 8(a) firms, contracts below that threshold are generally awarded on a sole-source basis, without competition among 8(a) firms. In this context, Alaskan Native Corporations (ANCs) are considered to be the 
Assistance Act (the so-called "Stafford Act"), which amended the earlier 1974 Disaster Relief Act, set-asides can also be provided for local firms during major disasters or emergencies..$^{73}$

Similar set-asides are also provided in Canada, where the federal government seeks to help Aboriginal communities, namely First Nations, Inuit and Métis, in "breaking down barriers to more fully participate in, and benefit from, the Canadian economy", enjoying the same opportunities for employment, income and wealth creation as other Canadians. ${ }^{74}$ In this context, the Federal Framework for Aboriginal Economic Development, launched in June 2009, seeks to promote a "business-friendly economic climate" for indigenous entrepreneurship "on reserve land and in the North, while improving access to capital and promoting other business opportunities, including procurement". ${ }^{75}$ In particular, specific mandatory and voluntary set-aside programs have been introduced by the Procurement Strategy for Aboriginal Business (PSAB). ${ }^{76}$

These two examples of national experiences show that public procurement, defined as a public policy tool instead of a simple administrative process, can be usefully conceived to achieve broader social objectives, such as the inclusive one. However, this implies the adoption of various capacity-building programmes for minority-owned businesses. As important component of a comprehensive preferential procurement system, governments must establish programmes that build the capacity of minority-owned businesses to "compete successfully in public procurement markets and deliver the goods and services that the governments require to fulfil their public functions". 77

Moreover, as with any system, "monitoring and evaluation are necessary to ensure compliance with preferential policies and programmes, to measure progress towards government or organizational objectives, and to make adjustments where necessary to improve the system". 78

With regards to the criticism related to the possible increased cost of social procurement, it should be clarified that the cost to be analysed is the global cost-benefit ratio of social considerations on the overall society in a longterm period rather than the mere costs of procurement outcome. The cost-benefit analysis should also take into account the impact of public procurement as an added-value in the State's policy toolbox: indeed, a general social policy needs a certain number of specific policy tools to make itself effective.

Moreover, the criticism related to the legitimacy of the inclusive considerations and the supplier diversity approaches through public procurement as regards to the competition principle does not take into account the fact that every public policy has to balance different needs and interests, often even conflicting with each other. Considering these conflicts requires a clear-cut legislative framework in order to identify needs and priorities: a one-size-fits-all approach is not the best policy solution.

All in all, when considering public procurement, responsible supply chains could be distinguished into the basic supply chain and the pro-active one. If the first should be the standard approach in business and public buyers' activities guaranteeing the fundamental human and labour rights, the second goes further in reaching social inclusive objectives and represents an extra step in the social-oriented approach. This does not imply that such further considerations are inconsistent with the primary objective of procurement or automatically increase the cost of procurement. However, a pro-active supply chain requires, first of all, a clear-cut public policy prioritizing different and conflicting social needs as well as specific monitoring systems.

most successful tenderers with at least one-third of all federal contracts awarded through the Small Business Administration's 8(a) business development program. See https://uscontractorregistration.com/qualify-for-set-aside-contracts-today/. See also Kate M. Manuel, Competition in Federal Contracting: An Overview of the Legal Requirements, Congressional Research Service 7-5700, 2011, available at www.crs.gov, p. 10.

${ }^{73}$ K. M. Manuel, Competition in Federal Contracting: An Overview of the Legal Requirements, Congressional Research Service 7-5700, 2011, available at www.crs.gov, p. 10. The Stafford Act provides that "[i]n the expenditure of Federal funds for debris clearance, distribution of supplies, reconstruction, and other major disaster or emergency assistance activities [...] carried out by contract or agreement with private [entities], preference shall be given, to the extent feasible and practicable, to those organizations, firms, and individuals residing or doing business primarily in the area affected by such major disaster or emergency".

74 https://www.aadnc-aandc.gc.ca/eng/1100100033498/1100100033499.

75 https://www.aadnc-aandc.gc.ca/eng/1100100033498/1100100033499.

76 https://www.aadnc-aandc.gc.ca/eng/1100100033498/1100100033499. While mandatory set-asides concern only federal contracts that serve a primarily Aboriginal population and are worth more than $\$ 5,000$, voluntary set-asides are left to the discretion of federal employees. In the latter case, federal contracting authorities are encouraged to voluntarily set aside opportunities for competition among Aboriginal businesses "whenever practical", meaning where Aboriginal capacity exists and sound contracting management can be assured and maintained. Aboriginal suppliers must be PSAB registered and self-certify that they meet two main criteria: at least 51 per cent of the ownership and control must be made by Aboriginal (applicable also for joint ventures in which an Aboriginal business or businesses have at least 51 per cent of the ownership and control), and at least 33 per cent of Aboriginal employees if the Aboriginal business has six or more full-time employees.

77 ITC, Empowering women through public procurement, 2014, available at: http://www.intracen.org/.

${ }^{78}$ ITC, Empowering women through public procurement, 2014, available at: http://www.intracen.org/. 


\section{CONCLUSIONS}

If "accommodating environmental concerns in public procurement has been gradual", ${ }^{79}$ social considerations seem to be subject to a slower implementation. This is partly due to the perception that social procurement is in contradiction with the primary objective of procurement and, worse, it is not economic efficient.

However, if we consider that public procurement is a flexible (i.e. capable of conforming to new needs) and multi-functional policy tool which can serve broader objectives than the mere obtaining of the needed work, good and service at the lowest possible price, we are recognising that public procurement is not a "mere administrative procedure by which public authorities purchase the basic products, services or works required for their operations". ${ }^{80}$ In other terms, beyond the administrative procedure in itself, there is a public tool which can be tailored to different policy priorities.

Moreover, if social objectives are considered as belonging to a strategic dimension - instead of to a simply "secondary" dimension - of public procurement, a shift in procurement policies should be envisaged to adopt a more strategically focused approach. This could lead to "obtain better value for each euro of public money spent and to contribute to a more innovative, sustainable, inclusive and competitive economy". ${ }^{81}$ But a legislative action and clear-cut policies and mechanisms are required at different stages, from policy prioritization to tender design, from efficiency matters to monitoring issues. 82

There are strong expectations from civil society and various organizations that public buyers take actions to promote the social responsibility of supply chains when buying goods, services and works. This does not imply that all social objectives can be reached at the same time through a procurement process. On the contrary, objectives should be realistic and ordered on a specific priorities-basis. Indeed, there are too many social needs competing with each other and affecting different dimensions (from working conditions to various social inclusive policies), to which one single approach is not easily applicable: one size does not fit all.

One way to prioritize different types of social needs is to distinguish between the basic supply chain and the proactive one, where the first could be considered as a standard approach in business and public buyers' activities guaranteeing the fundamental human and labour rights, while the second is an extra step in the social-oriented approach which goes further in reaching social inclusive objectives.

In both cases, when it comes to economic impact of such considerations, the focus should be on the global cost-benefit for the overall society in the long-term period rather than the simple cost of the procurement outcome. Moreover, through forms of collaboration between public authorities, the cost of both monitoring scheme and human resources' professionalization could be reduced by sharing experiences, information, mechanisms, and experts. Conversely, the current framework presents a fragmented patchwork of domestic experiences of different contracting authorities. Their approaches towards verification and monitoring are differing "both in focus (e.g. exclusion of child labour, core ILO Conventions or other ethical trading objectives) and in extent (e.g. simple bidder declarations, codes of conduct, labels and certification, follow-up questionnaires and audits)". .83

Public procurement may help in addressing "many of Europe's major challenges", including the creation of sustainable growth and (decent) jobs, as well as more equal and inclusive societies, but this requires a clear legislative and policy framework, specific monitoring mechanisms as well as a strong collaboration between contracting authorities, without overlooking the role that non-governmental organisations and other stakeholders operating in the field of sustainable development can play in achieving a more responsible public procurement system. ${ }^{84}$

\footnotetext{
${ }^{79}$ B. Martinez Romera and R. Caranta, EU Public Procurement Law: Purchasing Beyond Price in the Age of Climate Change, in EPPPL 3/2017, 2017, p. 286. "Concerns about the proper functioning of the internal market have slowed progress down. Progress has often only been possible thanks to case law forcing the hand of (some services in) the Commission, the self-styled high priest of internal market orthodoxy".

${ }^{80}$ Communication from the Commission to the European Parliament, the Council, the European Economic and Social Committee and the Committee of the Regions, COM(2017) 572 final, Making Public Procurement work in and for Europe, Strasbourg, 3.10.2017, p. 3, available at: http://ec.europa.eu/docsroom/documents/25612. "A shift from a purely administrative approach to a strategically and needs-driven approach, in full compliance with the rules" is required. Moreover, the Commission has identified six priority areas, "where clear and concrete action can transform public procurement into a powerful instrument in each Member State's economic policy toolbox, leading to substantial benefits in procurement outcomes". The first strategic priority underlined is the ensuring of wider uptake of strategic public procurement.

${ }^{81}$ Communication from the Commission to the European Parliament, the Council, the European Economic and Social Committee and the Committee of the Regions, COM(2017) 572 final, Making Public Procurement work in and for Europe, Strasbourg, 3.10.2017, p. 2, available at: http://ec.europa.eu/docsroom/documents/25612.

82 Communication from the Commission to the European Parliament, the Council, the European Economic and Social Committee and the Committee of the Regions, COM(2017) 572 final, Making Public Procurement work in and for Europe, Strasbourg, 3.10.2017, p. 3, available at: http://ec.europa.eu/docsroom/documents/25612.

83 The Landmark Project, Good Practice in Socially Responsible Public Procurement. Approaches to Verification from Across Europe, p. 4, available at: http://www.landmark-project.eu/fileadmin/files/en/latest-achievements/LANDMARK-good_practices_FINAL.pdf.

${ }^{84}$ Communication from the Commission to the European Parliament, the Council, the European Economic and Social Committee and the Committee of the Regions, COM(2017) 572 final, Making Public Procurement work in and for Europe, Strasbourg, 3.10.2017, p. 3, available at: http://ec.europa.eu/docsroom/documents/25612
} 


\section{REFERENCES}

Arrowsmith, S. (2010). Horizontal policies in public procurement: a taxonomy. Journal of Public Procurement, 10(2), 149-186.

Arrowsmith, S. and Kunzlik, P. (Eds.). (2009). Social and environmental Policies in EC Public Procurement Law, Cambridge University Press. https://doi.org/10.1017/CBO9780511576041

Caranta, R. (2014). Sustainable Procurement, in M. Trybus, R. Caranta, G. Edelstam (Eds.). EU Public Contract Law. Public Procurement and Beyond. Brussels, Bruylant.

Caranta, R. and Trybus, M. (Eds.). (2010). The law of Green and Social Procurement in Europe, Copenhagen, Djøf.

Clapp, J. M. Are Small Business Set-Asides Successful? Available at: http:/ /www.academia.edu/7353444/Are_Small_Business_Set-Asides_Successful

Costantini, S. (2014). La Finalizzazione Sociale degli Appalti Pubblici. Le "Clausole Sociali" fra Tutela del Lavoro e Tutela della Concorrenza, in Working Papers CSDLE Massimo D’Antona.it. Available at: http://csdle.lex.unict.it

Dragos, D. C. and Neamtu, B. (2014). Sustainable Public Procurement in the EU: Experiences and Prospects, in F. Lichere, R. Caranta, S. Treumer (Eds.). Novelties in the 2014 Directive on Public Procurement. Copenhagen, DJØF Publishing.

European Commission, Communication from the Commission to the European Parliament, the Council, the European Economic and Social Committee and the Committee of the Regions, COM. (2017). 572 final, Making Public Procurement work in and for Europe, Strasbourg, 3.10.2017. Available at: http:/ / ec.europa.eu/docsroom/documents/25612

European Commission. (2010). Buying social - A Guide to Taking Account of Social Considerations in Public Procurement.

European Human Rights Convention. Available at: http://www.echr.coe.int/Documents/Convention_ENG.pdf Friedman, H. (2014). Why Small Business Self-Certification should be Abolished and Replaced: A Case Against Fraud. Journal of Contract Management, 12.

ILO Fundamental Conventions. Available at: http://www.ilo.org

ITC. (2014). Empowering women through public procurement. Available at: http://www.intracen.org/

Kirkwood, W. (2016). The evolution of small business preferences in the United States and selected lessons learned for the European Union. EPPPL 4/2016.

Manuel, K. M. (2011). Competition in Federal Contracting: An Overview of the Legal Requirements, (Congressional Research Service 7-5700, 2011). Available at: http://www.crs.gov

Martin-Ortega, O. and Davies, A. (2017). MBA FCIPS, Protecting human rights in the supply chain. A guide for public procurement practitioners. Available at: http://www.hrprocurementlab.org/wpcontent/uploads/2017/06/KnowledgeLUPC-ProtectingHumanRightsintheSupplyChain2.pdf

Martin-Ortega, O. and Outhwaite, O. (2017). Monitoring Human Rights in Global Supply Chains. Insights and policy recommendations for civil society, global brands and academics, in BHRE Research Series, Policy Paper No. 3. Available at: http://www.bhre.org/policy-papers

McCrudden, C. (2015). Buying social justice: Equality, Government Procurement, and Legal Change. New York, Oxford University Press.

McCruden, C. (2009). EC public procurement law and equality linkages: foundations for interpretations, in S. Arrowsmith and P. Kunzlik (Eds.). Social and Environmental Policies EC Procurement Law. New Directives and New Directions, Cambridge-New York, Cambridge University Press. https://doi.org/10.1017/CBO9780511576041.009

OECD. (2017). Due Diligence Guidance for Responsible Supply Chains in the Garment and Footwear Sector.

OECD. (2014). Statement by the National Contact Points for the OECD Guidelines on Multinational Enterprises. One Year after Rana Plaza.

OECD. (2011). Guidelines for Multinational Enterprises (EMNs). Available at: http:/ /mneguidelines.oecd.org/responsible-business-conduct-matters.htm

Piga, G. and Tatrai, T. (Eds.). (2016). Public procurement policy. London and New York, Routledge.

Piga, G. and Tatrai, T. (2016). Supporting social considerations through public procurement: economic considerations, in G. Piga and T. Tatrai (Eds.). Public procurement policy. London and New York, Routledge.

Romera, B. M. and Caranta, R. (2017). EU Public Procurement Law: Purchasing Beyond Price in the Age of Climate Change, in EPPPL 3/2017.

Roos, R. (2012). Sustainable Public Procurement: Briefing Note. Available at: http://unpcdc.org/media/390120/spp_brief_en_2012-02-06.pdf

Sanchez Graells, A. (2015). Public procurement and the EU competition rules, (2nd edition). Oxford and Portland, Oregon, Hart Publishing. 
Schooner, S. L. and Yukins, C. R. (2009). Public procurement: focus on people, value for money and systemic integrity, not protectionism, in R. Bladwin and S. J. Evenett (Eds.). The Collapse of Global Trade, Murky Protectionism, and the Crisis: Recommendations for the G20. London, Centre for Economic Policy Research.

Schulten, T. et al. (2012). Pay and other social clauses in European public procurement. An overview on regulation and practices with a focus on Denmark, Germany, Norway, Switzerland and the United Kingdom, Düsseldorf, Study on behalf of the European Federation of Public Service Unions - EPSU. Available at: https://www.boeckler.de/pdf/wsi_schulten_pay_and_other_social_causes.pdf

Sjafjell, B. and Wiesbrock, A. (Eds.). Sustainable Public Procurement under EU Law: New Perspectives on the State as Stakeholder. Cambridge and New York, Cambridge University Press. https://doi.org/10.1017/CBO9781316423288

The Landmark Project, Success stories in socially responsible public procurement. (2014). Using public spending to drive improvements for workers in global supply chains. Available at: http://www.landmarkproject.eu/fileadmin/files/en/LANDMARK_Success_Stories_2014_-_eng.pdf

The Landmark Project, Good Practice in Socially Responsible Public Procurement. Approaches to Verification from Across Europe, p. 4. Available at: http://www.landmark-project.eu/fileadmin/files/en/latestachievements/LANDMARK-good_practices_FINAL.pdf

The Landmark Project, Verifying Social Responsibility in Supply Chains. A Practical and Legal Guide for Public Procurers, p. 5. Available at: http://www.landmark-project.eu/fileadmin/files/en/latestachievements/LANDMARK-legal_guidance-www.pdf

Trybus, M. (2016). Supporting social considerations through public procurement: a legal perspective, in G. Piga and T. Tatrai (Eds.). Public procurement policy. London and New York, Routledge. https://doi.org/10.2139/ssrn.2854205

Ulfbeck, V. (2017). Supply Chain Liability of the Public Buyer? in EPPPL 3/2017 (p. 325-332).

UN Convention on the Rights of the Child. Available at: http://www.un.org

UN Global Compact.

UN Guiding Principles on Business and Human Rights (UNGP).

UN Human Rights declaration. Available at: http:/ / www.un.org/en/universal-declaration-human-rights/

United Kingdom's Modern Slavery Act. (2015). 